\title{
THE EFFECT OF CARBETOCIN COMPARED TO RECTAL MISOPROSTOL IN THE MANAGEMENT OF BLOOD LOSS DURING THE THIRD STAGE OF VAGINAL DELIVERY IN LOW RISK PATIENTS FOR POSTPARTUM HEMORRHAGE
}

\author{
By
}

\section{Ahmed Sameer Abd El-Wahab, Abd Allah Khalil Ahmed and Al-Refaai Abd El-Fattah Marai}

Department of Obstetrics and Gynecology Faculty of Medicine, Al-Azhar University

Corresponding author: Ahmed Sameer Abd El-Wahab,

Mobile: (+20) 1112558287, E-mail: drahmedsameer1234@gmail.com

\begin{abstract}
Background: Postpartum hemorrhage (PPH) or excessive bleeding at or after childbirth is a potentially lifethreatening complication and is one of the major contributors to maternal mortality and morbidity worldwide.

Objective: To compare the effect of IV Carbetocin and Rectal Misoprostol to decrease blood loss in third stage of vaginal delivery in low risk patients for postpartum hemorrhage.

Patients and Methods: A randomized controlled trial was performed at Beni Suef Specialized Hospital in Obstetric Unit. The study included 160 healthy women with viable normal singleton pregnancy achieving normal vaginal delivery at or beyond 37 gestations from March 2019 till August 2019. Women were randomized to receive either a single dose Of Carbetocin $100 \mathrm{mcg}$ following delivery of the anterior shoulder of baby or rectal misoprostol $800 \mathrm{mcg}$ (4 tabs) at the crowning in the second stage of labor.

Results: There was non-statistically significant difference in the estimated mean blood loss between the carbetocin and misoprostol groups with blood loss of $203 \mathrm{ml}$ higher in misoprostol group. The mean drop of hemoglobin concentration $12 \mathrm{~h}$ after delivery was $0.63 \mathrm{~g} / \mathrm{dl}$ in carbetocin group and $1.1 \mathrm{~g} / \mathrm{dl}$ in misoprostol group and drop in hematocrit value was $1.9 \%$ in carbetocin group and $3.3 \%$ in misoprostol group. These differences were statistically non-significant in both groups. Women in the carbetocin group were more likely to experience abdominal pain than misoprostol group. Headache and tachycardia were predominate in carbetocin group, women needed other uterotonic drugs more in misoprostol group. Blood transfusion was needed in some misoprostol group cases.

Conclusion: Single dose of carbetocin $100 \mathrm{mcg}$ was with the same effect to $800 \mathrm{mcg}$ (4 tablets) misoprostol to decrease blood loss in third stage of normal vaginal delivery of low risk patients for postpartum hemorrhage, with no significant drop in hemoglobin and hematocrit in two groups but with more side effects and more cost in carbetocin group than misoprostol group.
\end{abstract}

Keywords: Carbetocin, Misoprostol, Blood Loss, Third Stage of Vaginal Delivery, Postpartum Hemorrhage.

\section{INTRODUCTION}

Systematic reviews have concluded that active management of third stage of labor, particularly the prophylactic use of uterotonic agents can significantly decrease the incidence of post-partum hemorrhage compared with that of 
expected management (Prendiville et al., 2010).

Uterine atony is defined as failure of the uterus to contract after child birth. It is the first cause of hemorrhage, approximately in 70 percent of cases (Oladapo et al., 2012).

Many evidences support the routine administration of oxytocin or ergot alkaloid for the prevention of $\mathrm{PPH}$ hemorrhage in order to enhance natural uterine contraction and retraction after CS and in the third stage of labor for VD, thus reducing the occurrence of PPH by $40 \%$ (Chong et al., 2012).

Over the last 2 decades, several alternative treatments have been explored including the use of prostaglandin (PGs) such as misoprostol and carboprost (Gulmezoglu et al., 2012). Oxytocin agonist, such as carbetocin that appears to be the most promising for this indication (Su et al., 2012).

A long acting synthetic analogue of oxytocin with agonist action has a half Life of 40 minutes, and uterine contractions occur in less than 2 minutes after IM or intravenous administration. The optimal dosage used in the Third stage of labor is 100 microgram (Leung et al., 2012).

Carbetocin is well tolerated and safety profile is similar to that of oxytocin. A single intravenous dose of carbetocin has been shown to be as effective as 16- hour intravenous oxytocin infusion to increase uterine tone and reduce the intra operative blood loss in women undergoing elective cesarean section (Larciprete et al., 2013).

Misoprostol is synthetic analogue of prostaglandin E1 that can be taken orally, sublingually, rectally and vaginally. Misoprostol is also used to prevent and treat post-partum bleeding (Allen and O'Brien, 2011).

The use of rectally administered misoprostol in cases of bleeding was shown to be associated with lower rates of side effects compared to other routes of misoprostol. It is inexpensive and thermo stable thus does not require refrigeration like oxytocin (Bradley et al., 2013).

The aim of this study was to compare the effect of IV Carbetocin $100 \mathrm{mcg}$ and rectal misoprostol $800 \mathrm{mcg}$ (4tab) in decrease blood loss in third stage of normal vaginal delivery in low risk patients for postpartum hemorrhage.

\section{PATIENTS AND METHODS}

This was a randomized controlled study done on one hundred and sixty pregnant women who underwent vaginal births. They were allocated into 2 groups (80 women for each group). Randomization was on alternative weekly manner as carbetocin given to patients delivered on Saturday, Monday and Wednesday, misoprostol given to patient delivered on Sunday, Tuesday and Thursday. The data collection began from March 2019 till August 2019 at Obstetric Unit of Beni Suef Specialized Hospital.

\section{Inclusion criteria:}

Age: 20-35years old, full term pregnancy >37 week and cephalic presentation.

\section{Exclusion criteria:}

High risk of post-partum hemorrhage e.g. twins, anemia, placenta praevia, polyhydramnios and previous history of postpartum hemorrhage, traumatic injury 
of birth canal (vaginal, perineal and cervical laceration) and vaginal delivery with operative delivery coagulopathy.

\section{All the patients were subjected to the following after taking informed written consent:}

1. Full history taking.

2. General examination including patient weight.

3. Abdominal examination including obstetric ultrasound for confirmation of gestational age of fetus, the fetus presentation and detection of placental site.

4. Routine laboratory tests including complete blood count and blood group.

Group 1 received 100 microgram carbetocin by I.V slowly for 1 minute administration at the time of delivery of the anterior shoulder of the baby according to the WHO recommendation for prevention of postpartum haemorrhage.

Group 2 received Misoprostol $800 \mathrm{mcg}$ (four tablets) per rectal at the crowning during second stage of labor.

\section{Active management of the labor was as the following:}

i. Administration of the carbetocin with delivery of the anterior shoulder of the baby or misoprostol at the crowning.

ii. Clamping and cutting the umbilical cord soon after birth.

iii. Applying controlled cord tension to the umbilical cord while applying simultaneous counter-pressure to the uterus, through the abdomen (BrandtAndrews technique of delivery of the placenta).
The patients were follow-up postpartum regarding vital signs and hemoglobin 12 hours after delivery. All women were assessed for the volume of blood loss: Pre-weight commonly used dry items during delivery (Towels). Quantification of blood loss started after the birth of the infant, but before delivery of the placenta.

Blood soaked materials and clots were weighed to determine the cumulative volume. The pre dry weight from the total blood soaked materials was subtracted to calculate blood loss (Chuang, 2019).

Before and after labor hemoglobin conc., need for other ecbolic to contract the uterus, need other intervention to control the bleeding or need blood transfusion were determined. Adverse effects of the drug were also checked as nausea, headache, abdominal pain and tachycardia.

\section{Statistical analysis:}

The collected data were coded, tabulated, and statistically analyzed using SPSS program (Statistical Package for the Social Sciences) software version 25. Descriptive statistics were done for parametric quantitative data by mean and Standard deviation, while they were done for categorical data by number and percentage. Distribution of the data was done by Kolomogorov Smirnov test. Analyses were done for parametric quantitative data between the two groups using independent samples $t$ test. Analyses were done for qualitative data using Chi square test (if less than $20 \%$ of cells have expected count $<5$ ) or Fisher's exact test (if more than $20 \%$ of cells have expected count $<5)$. The level of significance was taken at $(\mathrm{P}$ value $<0.05)$. 


\section{RESULTS}

Age was not statistically different between Carbetocin group and Misoprostol group (P 0.236). Weight was not statistically different between Carbetocin group and Misoprostol group (P 0.999). Gestational age was not statistically significant between
Carbetocin group and Misoprostol group (P 0.01). Parity was not statistically different between Carbetocin group and Misoprostol group (P 0.034). Blood loss was more in misoprostol group than in carbetocin group, but that was not statistically significant (p0.090) (Table 1).

Table (1): Demographic data of patients in the two studied groups as regard to maternal age, weight, gestational age, parity and blood loss

\begin{tabular}{|c|c|c|c|c|}
\hline \multicolumn{2}{|c|}{$\begin{array}{ll}\text { Parameters } & \text { Groups }\end{array}$} & Carbetocin N=80 & Misoprostol N=80 & $P$ value \\
\hline Age (Year) & $\begin{array}{c}\text { Range } \\
\text { Mean } \pm \text { SD }\end{array}$ & $\begin{array}{c}(20-35) \\
28.24 \pm 4.26\end{array}$ & $\begin{array}{l}(21-34) \\
29 \pm 3.81\end{array}$ & 0.236 \\
\hline Weight (Kg) & $\begin{array}{c}\text { Range } \\
\text { Mean } \pm \text { SD }\end{array}$ & $\begin{array}{c}(4-8-97) \\
70 \pm 12.78\end{array}$ & $\begin{array}{c}(52-95) \\
70 \pm 10.04\end{array}$ & 0.999 \\
\hline GA (Weeks) & $\begin{array}{c}\text { Range } \\
\text { Mean } \pm \text { SD }\end{array}$ & $\begin{array}{c}(36-40) \\
37.83 \pm 1.26\end{array}$ & $\begin{array}{c}(37-40) \\
38.24 \pm 1.17\end{array}$ & 0.034 \\
\hline Parity & $\begin{array}{c}\text { Range } \\
\text { Mean } \pm \text { SD }\end{array}$ & $\begin{array}{c}(1-5) \\
2.04 \pm 1.09\end{array}$ & $\begin{array}{c}(1-4) \\
1.84 \pm 0.96\end{array}$ & 0.220 \\
\hline $\begin{array}{l}\text { Blood loss } \\
(\mathrm{ml})\end{array}$ & $\begin{array}{c}\text { Range } \\
\text { Mean } \pm \text { SD }\end{array}$ & $\begin{array}{c}(111-660) \\
302.8 \pm 129.45\end{array}$ & $\begin{array}{c}(217-855) \\
508.3 \pm 168.14\end{array}$ & $<0.001$ \\
\hline
\end{tabular}

Independent samples $t$ test for quantitative data between the two groups

*: Significant difference at $\mathrm{P}$ value $<0.05$

Table (2) As regards to nausea, abdominal pain, diarrhea, vomiting, headache, tachycardia, fever, tremors and chills, there was no statistically different change between the two groups. However, there was abdominal pain in carbetocin group which was statistically significant (Table 2). 
Table (2): Occurrence of nausea, abdominal pain, diarrhea , vomiting, headache, tachycardia, fever, tremors and chills as a complication of drugs in two studied groups

\begin{tabular}{|c|c|c|c|c|}
\hline \multicolumn{2}{|c|}{ Parameters $\quad$ Groups } & $\begin{array}{c}\text { Carbetocin } \\
\mathbf{N}=\mathbf{8 0}\end{array}$ & $\begin{array}{l}\text { Misoprostol } \\
\mathrm{N}=\mathbf{8 0}\end{array}$ & $P$ value \\
\hline Nausea & $\begin{array}{l}\text { No } \\
\text { Yes }\end{array}$ & $\begin{array}{c}80(100 \%) \\
0(0 \%)\end{array}$ & $\begin{array}{c}80(100 \%) \\
0(0 \%)\end{array}$ & 1 \\
\hline Abdominal pain & $\begin{array}{l}\text { No } \\
\text { Yes }\end{array}$ & $\begin{array}{l}70(87.5 \%) \\
10(12.5 \%)\end{array}$ & $\begin{array}{c}80(100 \%) \\
0(0 \%)\end{array}$ & 0.001* \\
\hline Diarrhea & $\begin{array}{l}\text { No } \\
\text { Yes }\end{array}$ & $\begin{array}{l}78(97.5 \%) \\
2(2.5 \%)\end{array}$ & $\begin{array}{c}77(96.2 \%) \\
3(3.8 \%)\end{array}$ & 1 \\
\hline Vomiting & $\begin{array}{l}\text { No } \\
\text { Yes }\end{array}$ & $\begin{array}{c}80(100 \%) \\
0(0 \%)\end{array}$ & $\begin{array}{c}80(100 \%) \\
0(0 \%)\end{array}$ & 1 \\
\hline Headache & $\begin{array}{l}\text { No } \\
\text { Yes }\end{array}$ & $\begin{array}{l}64(80 \%) \\
16(20 \%)\end{array}$ & $\begin{array}{l}72(90 \%) \\
8(10 \%)\end{array}$ & 0.120 \\
\hline Tachcardia & $\begin{array}{l}\text { No } \\
\text { Yes }\end{array}$ & $\begin{array}{l}78(97.5 \%) \\
2(2.5 \%)\end{array}$ & $\begin{array}{c}80(100 \%) \\
0(0 \%)\end{array}$ & 0.497 \\
\hline Fever & $\begin{array}{l}\text { No } \\
\text { Yes }\end{array}$ & $\begin{array}{c}75(93.7 \%) \\
5(6.3 \%)\end{array}$ & $\begin{array}{l}70(87.5 \%) \\
10(12.5 \%)\end{array}$ & 0.278 \\
\hline Tremors & $\begin{array}{l}\text { No } \\
\text { Yes }\end{array}$ & $\begin{array}{c}76(95 \%) \\
4(5 \%)\end{array}$ & $\begin{array}{c}74(92.5 \%) \\
6(7.5 \%)\end{array}$ & 0.756 \\
\hline Chills & $\begin{array}{l}\text { No } \\
\text { Yes }\end{array}$ & $\begin{array}{c}77(96.2 \%) \\
3(3.8 \%)\end{array}$ & $\begin{array}{l}72(90 \%) \\
8(10 \%)\end{array}$ & 0.210 \\
\hline
\end{tabular}

Thera war no statistically different change in the occurrence of uterine contraction and patients needed for blood transfusion between two groups (Table3).

Table (3): Comparison between the two groups regarding severity of uterine contraction and patients needed for blood transfusion

\begin{tabular}{|c|c|c|c|c|}
\hline \multicolumn{2}{|c|}{$\begin{array}{ll}\text { Parameters } & \text { Groups } \\
\end{array}$} & $\begin{array}{c}\text { Carbetocin } \\
\mathbf{N}=\mathbf{8 0}\end{array}$ & $\begin{array}{c}\text { Misoprostol } \\
\mathbf{N}=\mathbf{8 0}\end{array}$ & $P$ value \\
\hline $\begin{array}{l}\text { Uterine } \\
\text { contraction }\end{array}$ & $\begin{array}{l}\text { Mild Moderate } \\
\text { Severe }\end{array}$ & $\begin{array}{c}8(10 \%) \\
36(45 \%) \\
36(45 \%)\end{array}$ & $\begin{array}{c}10(12.5 \%) \\
42(52.5 \%) \\
28(35 \%)\end{array}$ & 0.431 \\
\hline $\begin{array}{c}\text { Blood } \\
\text { transfusion }\end{array}$ & $\begin{array}{l}\text { No } \\
\text { Yes }\end{array}$ & $\begin{array}{c}80(100 \%) \\
0(0 \%)\end{array}$ & $\begin{array}{l}77(96.2 \%) \\
3(3.8 \%)\end{array}$ & 0.245 \\
\hline
\end{tabular}

\section{DISCUSSION}

This study was done at Obstetrics Unit of Beni Suef Specialized Hospital. One hundred and sixty pregnant women who underwent vaginal births were recruited in this study. They were allocated into 2 equal groups. Randomization was undertaken by alternative weekly manner. Our results have shown that carbetocin was superior to misoprostol in decrease the amount of blood loss after vaginal delivery studied groups. As in carbetocin group, the mean blood loss was $302.8 \mathrm{ml}$ and in misoprostol group the mean blood loss was $508.3 \mathrm{ml}$ with statistical significant deference.

Bellad et al. (2012) performed doubleblind randomized controlled trial consenting eligible pregnant women admitted to the labor room prevention of 
postpartum hemorrhage with sublingual misoprostol or oxytocin.

The incidence of PPH was $3.1 \%$ with misoprostol and $9.1 \%$ with oxytocin. No woman lost $1000 \mathrm{ml}$ of blood. They observed that $9.7 \%$ and $45.6 \%$ of women experienced a hemoglobin decline of $>10 \%$ after receiving misoprostol and oxytocin, respectively. Side effects were significantly greater in the misoprostol group than in the oxytocin group.

Maged et al. (2016) performed prospective randomized study and found that the amount of blood loss and the need for other uterotonics were significantly lower in the carbetocin group. There was no significant difference between the Carbetocin and oxytocin group regarding occurrence of major $\mathrm{PPH}$, the need for blood transfusion, the difference between blood hemoglobin levels before delivery and $24 \mathrm{~h}$ after delivery.

Our study disagreed with this in amount of blood loss in carbetocin group versus misoprostol group. The need for other uterotonic drugs was less in carbetocin group $9 / 80$ vs $25 / 80$ in misoprostol group. Our study also disagree with need for blood transfusion as in carbetocin group there wasn't any patient need blood transfusion vs 3 cases in misoprostol group need for blood transfusion.

Abd Aziz et al. (2017) have prospective, randomized study and found that carbetocin was superior to misoprostol with lower duration of third stage of labour, lower amount of blood loss and lower incidence of PPH. There was no significant difference in the predelivery and the post-delivery hemoglobin concentration between the two groups.
The need of additional uterotonics and blood transfusion was higher with misoprostol as compared to carbetocin. As regards side effects, misoprostol was associated with shivering and pyrexia as compared to cabetocin while nausea, vomiting and headache were more associated with cabetocin.

This agreed with our result in difference of the post-delivery haemoglobin concentration between both groups as it was not statistically significant.

Our study disagreed in amount of blood loss between both groups, the need for other uterotonic drugs and blood transfusion also higher in misoprostol group than carbetocin group, but also without statistically significant, regards side effects abdominal pain, headache and tachycardia more in carbetocin groups.

In our results, misoprostol was effective as an injectable uterotonic drug in reducing blood loss, mean loss with misoprostol. Also, misoprostol group increased the need for additional uterotonic drugs to misoprostol group and side effects were dose related. Incidence of abdominal pain was less in misoprostol.

Attilakos et al. (2010) performed double-blind randomized study women at term undergoing elective or emergency caesarean section under regional anesthesia, excluding women with placenta praevia, multiple gestations and women were randomised to receive either carbetocin $(100 \mu \mathrm{g})$ or oxytocin (5 IU) intravenously after the delivery of the baby. Significantly more women needed additional oxytocics in the oxytocin group. The majority of women had oxytocin infusions. There were no 
significant differences in the secondary outcomes, including major PPH, blood transfusions and fall in hemoglobin. Carbetocin is associated with a reduced use of additional oxytocics.

This agreed with our results in carbetocin group, but in misoprostol group needed additional uterotonic drugs. Carbetocin was associated with reduced use of additional oxytocics and agreed with our results that there were no significant differences in the need for blood transfusions and change in hemoglobin before and after delivery.

Leung et al. (2012) performed prospective, double-blinded, randomized study on women with a singleton pregnancy achieving vaginal delivery beyond 34-week gestation were eligible for the study pared IM administration of carbetocin and Syntometrine. Randomized to receive either a single dose of 100 microgram IM carbetocin or $1 \mathrm{ml}$ IM syntometrine (a mixture of 5 iu oxytocin and $0.5 \mathrm{mg}$ ergometrine) at the end of second stage of labor difference in hemoglobin drop measured 2 days after delivery. There was no difference in the drop of hemoglobin concentration within the first 48 hours between the two groups. The incidence of additional oxytocic injections, postpartum hemorrhage (blood loss $>$ or $=500 \mathrm{ml}$ ) and retained placenta were also similar. The use of carbetocin was associated with significant lower incidence of nausea. This agreed with our result regarding carbetocin group side effects tachycardia blood loss and change in hemoglobin as in carbetocin group less drop in hemoglobin and blood loss with on statically significant, need for other uterotonic drugs is also less in carbetocin group.

\section{CONCLUSION}

Carbetocin seems to be the same effectiveness to misoprostol in maintaining adequate uterine tone and preventing excessive blood loss in patients after vaginal delivery at low risk to develop postpartum hemorrhage, but misoprostol is preferred due to its low cost, thermo stable and the high rates of side effects for the carbetocin.

However, larger sample size may be required in following studies with application of different routes of administration and different doses and evaluation of their effect.

\section{REFERENCES}

1. Abd Aziz K, Ibrahim $M$ and Samy A (2017): Prevention of postpartum haemorrhage in patients with severe preeclampsia using carbetocin versus misoprosto. Apollo Medicine, 14 (2): 117122.

2. Allen R and O'Brien BM (2011): Uses of misoprostol in obstetrics and gynecology. Rev Obstet Gynecol, 2(3):159-68.

3. Attilakos G, Psaroudakis D, Ash J, Buchanan $R$ and Winter $C$ (2010): Carbetocin versus oxytocin for the prevention of postpartum haemorrhage following caesarean section: the results of a doubleblind randomized trial. BJOG, 117:929-36.

4. Bellad MB, Tara D, Ganachari M, Mallapur M, Goudar S, Kodkany B, Sloan $N$ and Derman $R$ (2012): Prevention of postpartum haemorrhage with sublingual misoprostol or oxytocin: a double-blind randomised controlled trial. BJOG, 119:9986.

5. Bradley SEK, Prata N, Young-Lin N and Bishai DM (2013): Cost Effectiveness of misoprostol to control postpartum 
hemorrhage in low-resource settings. Gynecology and Obstetrics, 97: 52-56.

6. Chong YS, Su LL and Arulkumaran S (2012): Current strategies for the prevention of postpartum haemorrhage in the third stage of labour. Curr Opin Obstet Gynecol., 16(2):143-50.

7. Chuang M (2019): Obstetrical hemorrhage: clinical updates, and the need for quantification of blood loss. Crit Car Obst Gyne., 5(2): 6.

8. Gulmezoglu AM, Tuncalp O and Hofmeyr GJ (2012): Prostaglandins for prevention of postpartum haemorrhage. Cochrane Database Syst Rev., (8):CD000494.

9. Larciprete G, Montagnoli C, Frigo M, Panetta V and Todde C (2013): Carbetocin versus oxytocin in caesarean section with high risk of post-partum haemorrhage. J Prenat Med, 7(1): 12-18.

10. Leung SW, Ng PS, Wong WY and Cheung TH (2012): A randomized trial of carbetocin versus syntometrine in the management of the third stage of labour. BJOG, 113:145964.
11. Maged AM, Hassan AM and Shehata NA (2016): Carbetocin versus oxytocin $n$ the management of atonic postpartum after vaginal delivery Arch Gynecol Obstet., 293(5):993-9.

12. Oladapo OT, Fawole B, Blum $\mathbf{J}$ and Abalos E (2012): Advance misoprostol distribution for preventing and treating postpartum haemorrhage. Cochrane Database of Systematic Reviews, Issue 2. Art. No.: CD009336.

13. Prendiville WJ, Elbourne D and McDonald S (2010): Active versus expectant management in the third stage of labour. Cochrane Database of Systematic Reviews, 3: CD000007.

14. Su LL, Chong YS and Samuel M (2012): Carbetocin for preventing postpartum haemorrhage. Cochrane Database of Systematic Reviews, 4: CD005457. 


\section{تأثير الكاربيتوسين مقارنة بالميزوبروستول الثرجي في

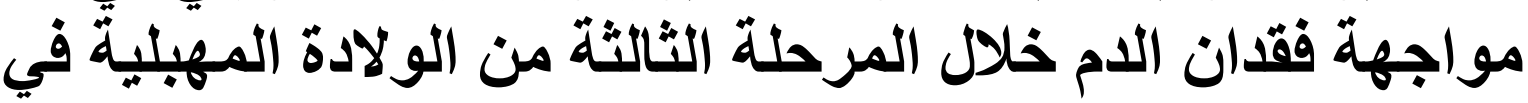

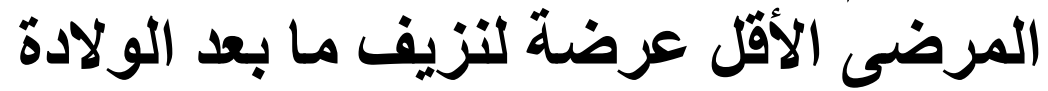 أحمد سمير عبد الوهاب، عبد الله خليل أحمد، الرفاعي عبد الفتاح مرعي} قسم أمراض النساء والتوليد، كلية الطب، جامعة الأزهر

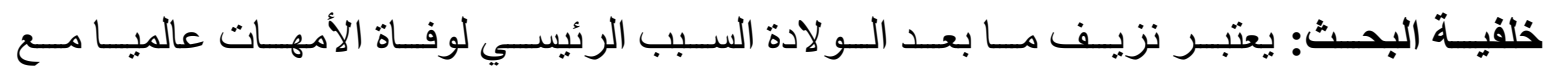

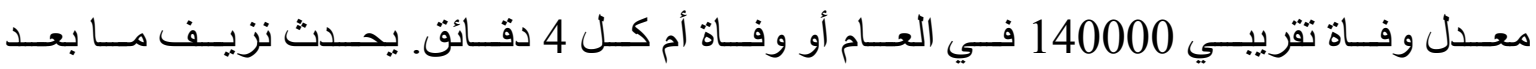

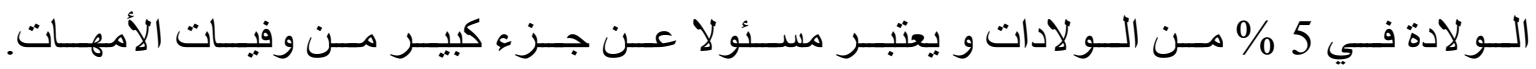

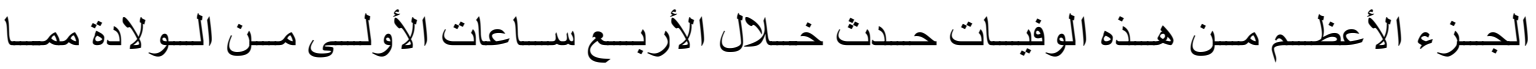

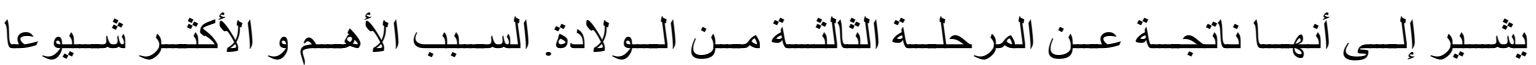

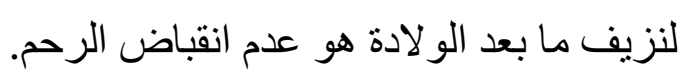

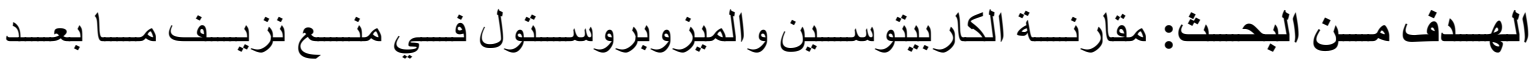

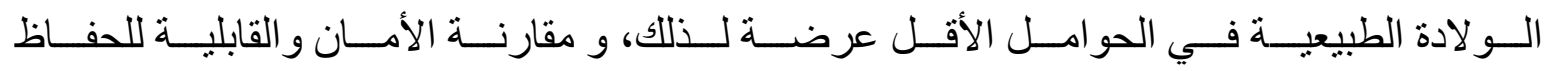

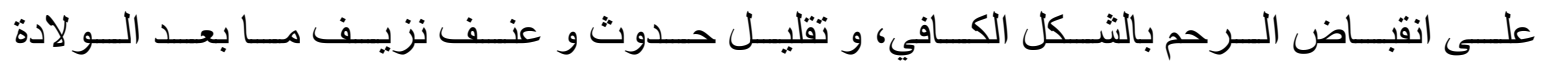

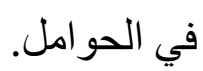

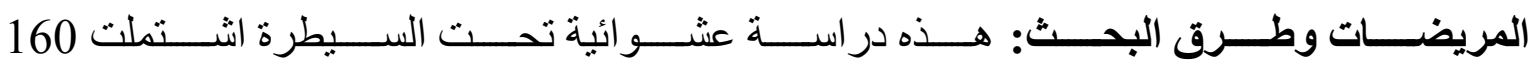

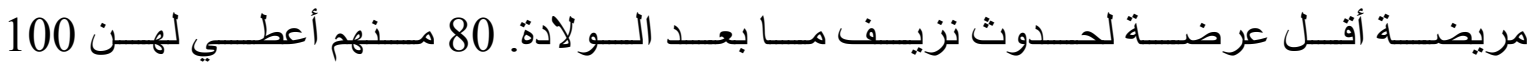

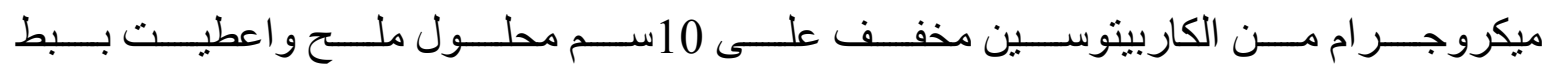

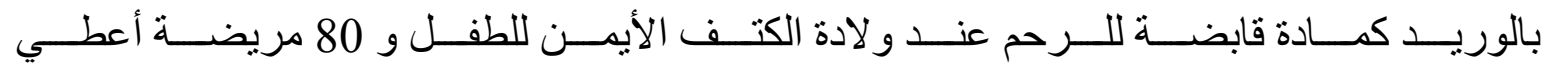

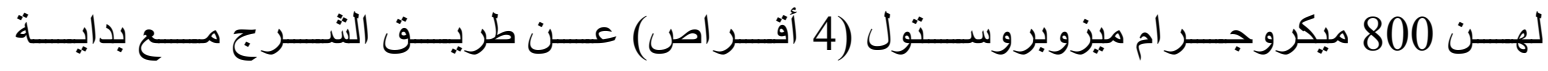

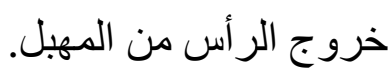

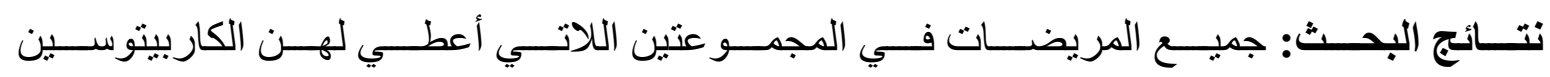

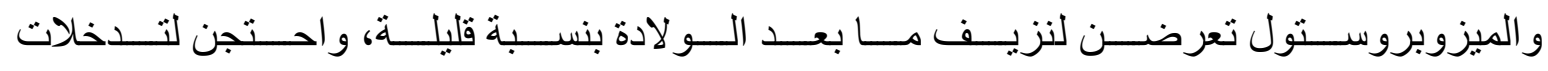

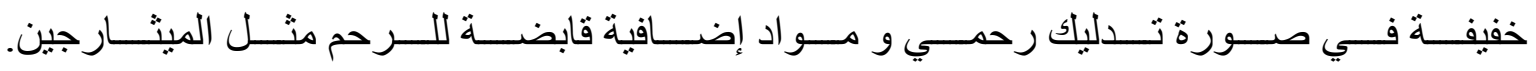

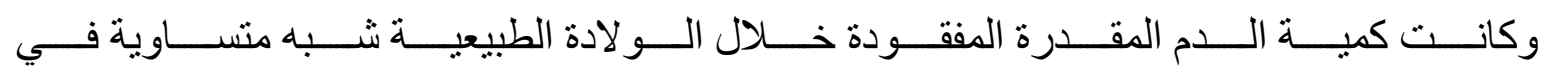

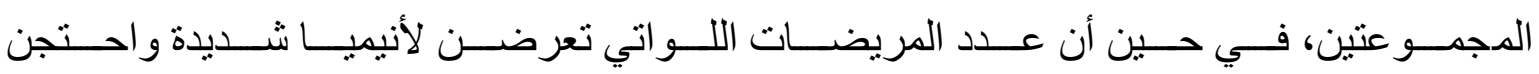




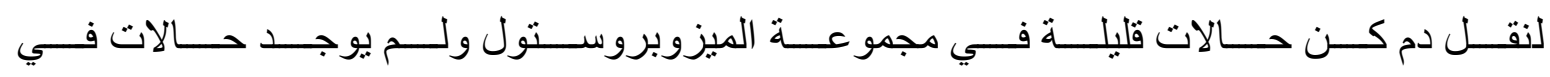

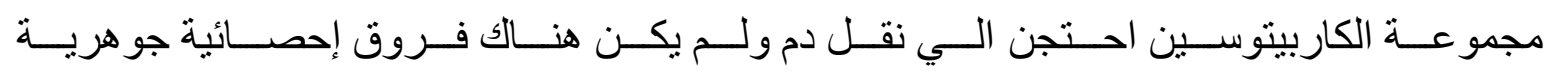

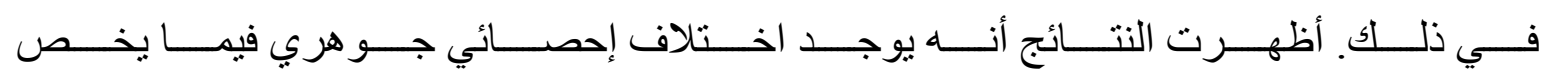

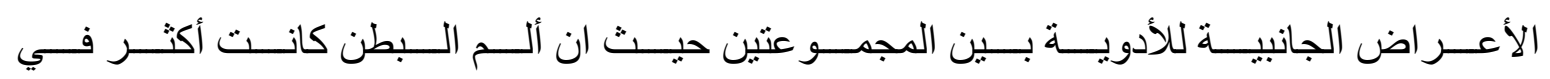

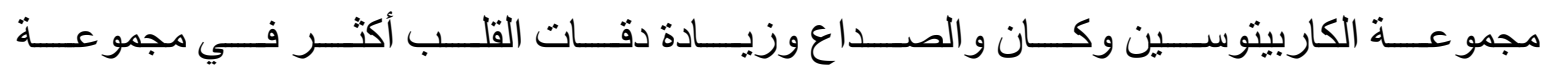

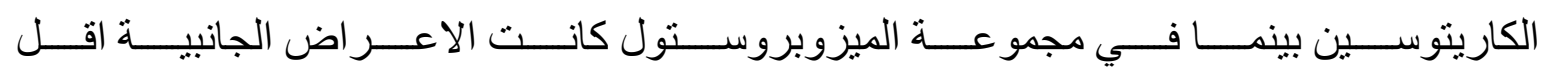
و غير ملحوظة.

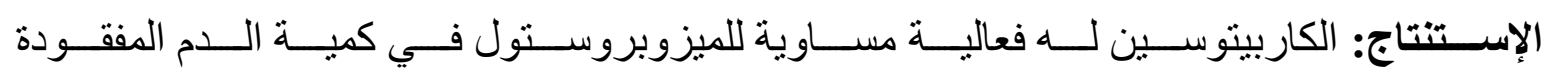

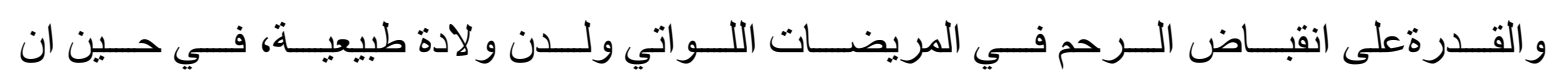

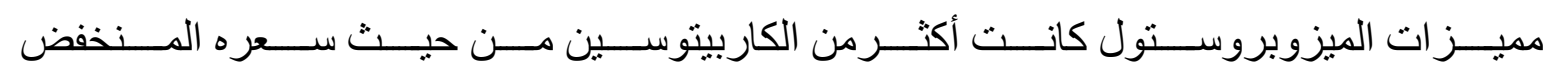
و استقر اره الحر اري بالاضافة الى مضاعفاته الجانبية الاقل. 